\title{
PENGARUH VARIETAS, FRAKSI PENGAYAKAN, DAN JENIS PELARUT TERHADAP KADAR ANTOSIANIN, FENOLIK TOTAL, DAN AKTIVITAS ANTIOKSIDAN EKSTRAK JAGUNG UNGU
}

\section{THE EFFECT OF VARIETIES, SIFTING FACTIONS, AND SOLVENTS ON TOTAL ANTHOCYANINS, TOTAL PHENOLIC CONTENTS, AND ANTIOXIDANT ACTIVITIES OF PURPLE CORN EXTRACTS}

\author{
Ichda Chayati ${ }^{1}$, Sunarti ${ }^{2}$, Yustinus Marsono ${ }^{3}$, Mary Astuti ${ }^{3}$ \\ ${ }^{1}$ Program Studi Tata Boga, Fakultas Teknik, Universitas Negeri Yogyakarta \\ Jl. Kampus, Karangmalang, Yogyakarta 55281 \\ ${ }^{2}$ Departemen Biokimia, Fakultas Kedokteran, Kesehatan Masyarakat, dan Keperawatan, \\ Universitas Gadjah Mada \\ Jl. Farmako, Sekip Utara, Yogyakarta 55281 \\ ${ }^{3}$ Departemen Teknologi Pangan dan Hasil Pertanian, Fakultas Teknologi Pertanian, \\ Universitas Gadjah Mada \\ Jl. Flora No. 1, Bulaksumur, Yogyakarta 55281 \\ e-mail: ichda_chayati@uny.ac.id
}

Diterima : 18-07-2019

Direvisi : 20-08-2019

Disetujui : 19-11-2019

\begin{abstract}
ABSTRAK
Penelitian bertujuan untuk mengetahui pengaruh varietas, fraksi pengayakan, dan jenis pelarut terhadap sifat kimia ekstrak jagung ungu yang meliputi kadar antosianin total, fenolik total, flavonoid total, dan aktivitas antioksidannya. Sampel yang digunakan adalah tiga varietas jagung ungu, yaitu Pulut Manado dari Sulawesi dan Malang Biasa serta Malang Pekat dari Jawa. Fraksi pengayakan meliputi fraksi tepung jagung ungu tanpa pengayakan, fraksi yang lolos ayakan, dan fraksi yang tidak lolos ayakan 60 mesh. Pembuatan ekstrak antosianin menggunakan variasi pelarut etanol-asam sitrat $3 \%$ dan aquades-asam sitrat 3\% (1:10), penguapan dengan rotary evaporator bersuhu $40^{\circ} \mathrm{C}$ atau $50^{\circ} \mathrm{C}$, tekanan 75 atau 175 mbar, selama 4-5 jam. Hasil penelitian menunjukkan bahwa dari semua parameter pengujian yang dilakukan, ekstrak jagung ungu varietas Malang Pekat dari fraksi yang tidak lolos ayakan 60 mesh dan menggunakan pelarut etanol-sitrat 3\% mempunyai kadar tertinggi, yaitu kadar antosianin total $2.553 \pm 48,6 \mathrm{mg}$ cyanidin-3-glucoside equivalent (CGE)/ L, kadar fenolik total $5.615 \pm 71,9 \mathrm{mg}$ gallic acid equivalent (GAE)/ $\mathrm{L}$, kadar flavonoid total $4.541 \pm 40,4 \mu \mathrm{g}$ rutin hydrate equivalent (RE)/ $\mathrm{L}$, aktivitas antioksidan metode DPPH 11.212 $\pm 148 \mu \mathrm{mol}$ Trolox equivalent (TE)/ $\mathrm{L}$, dan aktivitas antioksidan metode FRAP $18.030 \pm 18,0 \mu \mathrm{mol}$ TE/ L. Ekstrak yang dibuat dari jagung ungu varietas Malang Pekat dari fraksi tidak lolos pengayakan 60 mesh dan diekstraksi dengan pelarut etanol-asam sitrat $3 \%$ tersebut sangat potensial sebagai sumber antosianin, yang dapat dimanfaatkan sebagai pengawet dan pewarna alami maupun sumber antioksidan eksogen.
\end{abstract}

Kata kunci: aktivitas antioksidan, antosianin, fenolik total, jagung ungu

\section{ABSTRACT}

The study aimed to determine the effect of varieties, sifting factions, and types of solvents on the chemical properties of purple corn extract (PCE), i.e. total anthocyanin, total phenolic, total flavonoid contents, and antioxidant activities. Three varieties of purple corn, i.e. Pulut Manado from Sulawesi, Malang Biasa and Malang Pekat from Java were used as samples. The sifting factions were the purple corn flour which were without sifting, passed 60 mesh sifting, or did not pass 60 mesh sifting. Purple corn extracts were made from ethanol-3\% citric acid or distilled water-3\% citric acid solvents (1:10, 
$m / v)$, evaporated with a rotary evaporator at $40^{\circ} \mathrm{C}$ or $50^{\circ} \mathrm{C}$, the pressure of 75 or $175 \mathrm{mbar}$, for $4-5$ hours. The results showed that of all parameters tested, the extract of Malang Pekatflourwhich was did not pass 60 mesh sifting using ethanol-3\% citric acid had the highest scores, i.e.total anthocyanin level was 2,553+48.6 mg cyanidin-3-glucoside equivalent (CGE)/ L, total phenolic content was5, $615 \pm 71.9 \mathrm{mg}$ gallic acid equivalent $(G A E) / L$, total flavonoid content was4,541 $440.4 \mu \mathrm{g}$ rutin hydrate equivalent (RE)/ $L$, antioxidant activity of DPPH method was 11,212 $\pm 148 \mu \mathrm{mol}$ Trolox equivalent (TE)/ L, antioxidant activity of FRAP method was18,030 $\pm 18.0 \mu \mathrm{mol} T E / \mathrm{L}$. Purple corn ethanolic extract of Malang Pekat obtained from the faction which did not pass 60 mesh siftingis a potential source of anthocyanins, which can be used as natural preservatives and colorants as well as exogenous antioxidants.

Keywords: antioxidant activity, anthocyanin, total phenolic, purple corn

\section{PENDAHULUAN}

M akhluk hidup memiliki sistem reduksi oksidasi (redoks) yang bertugas untuk menjaga kehidupan manusia berada pada keseimbangan yang sehat (Jing, 2006). Dalam tubuh manusia yang sehat dan normal, reactive oxygen species (ROS) dan reactive nitrogen species (RNS) sebagai hasil proses oksidasi secara efektif dijaga kadarnya oleh berbagai tingkat pertahanan antioksidan. Antioksidan meliputi dua macam yaitu antioksidan endogen berupa enzim dan non-enzim, dan antioksidan eksogen yang berasal dari makanan (Bouayed dan Bohn, 2010). Redoks dapat kehilangan keseimbangan karena akumulasi prooksidan yang berasal dari faktor internal, misalnya kegelisahan, kelelahan, penyakit, kekurangan oksigen, produksi ROS dari mitokondria, dan lain-lain, serta faktor eksternal misalnya polusi, sinar matahari, merokok, iklim, makanan, dan lain-lain (Rahal et al., 2014). Akumulasi senyawa prooksidan tersebut berpengaruh terhadap fosforilasi/defosforilasi dan oksidasi residu thiol yang menyebabkan perubahan atau modifikasi jalur pensinyalan nuklear faktor kappa beta (NF-kB) dan berakibat menurunnya aktivitas antioksidan endogen enzimatis dan non-enzimatis, berakibat pada kondisi stres oksidatif (Siomek, 2012; Kurutas, 2016). Stres oksidatif menyebabkan penuaan dan terlibat dalam etiologi lebih dari seratus penyakit manusia seperti kanker, penyakit jantung, penurunan sistem kekebalan, disfungsi otak, katarak, dan lain-lain (Jing, 2006).

Kondisi stres oksidatif menyebabkan kebutuhan antioksidan meningkat. Antioksidan adalah substansi yang mampu menghambat, mencegah, atau menghilangkan kerusakan oksidatif pada molekul target (Halliwell, 2007). Stres oksidatif yang dipicu melalui jalur NF-kB tidak dapat diatasi oleh antioksidan endogen, oleh karena itu tubuh memerlukan asupan antioksidan eksogen. Salah satu antioksidan eksogen adalah antosianin.

Selain sebagai antioksidan yang dapat dimanfaatkan sebagai pengawet alami makanan dan bermanfaat untuk kesehatan tubuh, antosianin juga bermanfaat sebagai pewarna makanan alami. Antosianin adalah kelompok terpenting dari pigmen tanaman yang merupakan kelompok senyawa flavonoid yang memberikan warna oranye, merah, ungu, dan warna biru cerah pada sebagian besar buah, biji-bijian, sereal, sayuran, dan bunga (Khoo et al., 2017).

Bahan pangan sumber antosianin dapat berasal dari bermacam-macam sumber, diantaranya jagung ungu, kedelai hitam, ceri cornelia, blueberry, stroberi, dan blackberry (Wu et al., 2013). Produk yang dibuat dari bahan baku yang mengandung antosianin, juga akan mengandung antosianin. Dalam produk permen jelly yang dibuat dengan penambahan ekstrak bunga rosella 15\% mengandung antosianin sebesar 3,5 mg/ $100 \mathrm{~g}$ (Susanti, 2015), sementara di dalam sari buah naga merah, kadar antosianin antara 1,67-2,39 ppm (Susanti dan Sampepana, 2017).

Indonesia memiliki kekayaan alam plasma nutfah jagung ungu, diantaranya adalah varietas Pulut Manado dari Sulawesi, Malang Biasa dan Malang Pekat dari Jawa. Produktivitas tanaman jagung ungu mencapai 6-8 ton per hektare tergantung musim, namun lahan tanaman 
ini masih terbatas di Sulawesi Selatan dan Jawa Timur (Firmansyah, 2018; Balai Penelitian Tanaman Serealia, 2018).

Jagung ungu memiliki antosianin dalam kisaran $290-1300 \mathrm{mg} / 100 \mathrm{~g}$ berat kering (bk) dengan komponen antosianin utama adalah cyanidin-3-glukosida (Jing, 2006). Antosianin dari jagung ungu didapatkan dengan proses ekstraksi, salah satunya ekstraksi dengan pelarut. Pelarut yang digunakan berbagai macam, beberapa diantaranya yang pernah diteliti adalah etanol (Li et al., 2014), aseton + air + $\mathrm{HCl}$ (Jing, 2006), methanol + air + $\mathrm{HCl}$ (Ramos-Escudero et al., 2012), metanol + $\mathrm{HCl}$ (Hu dan Xu, 2011), aquades+asam sitrat (Napan et al., 2018), danetanol + asam sitrat (Fernandez-Auliset al., 2019).

Penelitian ini bertujuan untuk mempelajari kadar antosianin total, fenolik total, flavonoid total, dan aktivitas antioksidan ekstrak jagung ungu yang berasal dari Sulawesi dan Jawa. Ekstrak jagung ungu kaya antosianin hasil penelitian ini diharapkan dapat menjadi alternatif bahan pangan sebagai sumber antosianin yang dapat dimanfaatkan sebagai pengawet dan pewarna alami maupun sebagai sumber antioksidan eksogen.

\section{METODOLOGI}

\section{Bahan}

Penelitian menggunakan tiga varietas jagung ungu lokal, yaitu jagung ungu Pulut Manado, Malang Biasa, dan Malang Pekat. Benih jagung ungu varietas Pulut Manado didapat dari Balai Penelitian Tanaman Serealia di Maros, Sulawesi Selatan sementara varietas Malang Biasa dan Malang Pekat didapat dari Fakultas Pertanian Universitas Brawijaya Malang. Jagung ungu kering ditepungkan dengan grinder dan disimpan dalam freezer $\left(-10^{\circ} \mathrm{C}\right)$ sampai saat digunakan.

Hidrat asam galat, asam askorbat, rutin hydrate, 2,2-diphenyl-1-picrylhydrazyl (DPPH), 2,4,6-tri(2-piridil)-s-triazine (TPTZ), dan Trolox, semua bahan tersebut dari Sigma. Semua bahan kimia dalam grade analitik dan dibeli dari Sigma-Aldrich dan Merck.

\section{Alat}

Peralatan yang digunakan adalah spektrofotometer UV-Vis Shimadzu, ultrasonic waterbath Grant, HPLC Shimadzu, rotary evaporator Buchi-3000, dan sentrifus dari Beckman.

\section{Tahapan penelitian}

Penelitian dilakukan melalui tiga tahapan. Tahap pertama penelitian bertujuan untuk mengetahui kadar antosianin total, fenolik total, flavonoid total, dan aktivitas antioksidan ekstrak antosianin dari tiga varietas jagung ungu sehingga diperoleh satu varietas jagung ungu dengan kadar antosianin paling tinggi. Tepung jagung ungu diekstraksi dengan pelarut etanolasam sitrat $3 \%(1: 10, \mathrm{~m} / \mathrm{v})$ dalam Erlenmeyer $2500 \mathrm{ml}$ menggunakan magnetic stirrer kecepatan $1000 \mathrm{rpm}$ pada suhu kamar selama 3 jam. Proses selanjutnya adalah sentrifugasi pada $3.000 x g$, pada suhu kamar selama 30 menit sehingga diperoleh supernatan. Supernatan yang dihasilkan selanjutnya diuapkan dengan rotary evaporator pada suhu $40^{\circ} \mathrm{C}$, tekanan 175 mbar, selama 4-5 jam. Ekstrak kental selanjutnya dikemas dalam botol gelap dengan di-seal dan disimpan dalam keadaan gelap dalam freezer $\left(-10^{\circ} \mathrm{C}\right)$ untuk analisis selanjutnya (Zhao et al., 2008 dengan modifikasi). Ekstrak kental yang didapatkan selanjutnya disebut ekstrak jagung ungu dan diuji sifat kimiawinya. Diagram alir penelitian tahap pertama dapat dilihat pada Gambar 1.

Penelitian tahap kedua bertujuan untuk mengetahui kadar antosianin total, fenolik total, flavonoid total, dan aktivitas antioksidan ekstrak antosianin dari hasil pengayakan. Bahan baku penelitian tahap kedua adalah varietas jagung ungu lokal terpilih hasil penelitian tahap 
pertama. Tepung jagung ungu digiling dan diayak dengan ayakan 60 mesh, sehingga didapat fraksi tanpa pengayakan, fraksi yang lolos pengayakan, dan yang tidak lolos pengayakan 60 mesh. Fraksi terpilih adalah fraksi tepung dengan kadar antosianin paling tinggi. Diagram alir penelitian tahap kedua dapat dilihat pada Gambar 2.

Penelitian tahap ketiga bertujuan untuk mengetahui kadar antosianin total, fenolik total, flavonoid total, dan aktivitas antioksidan ekstrak jagung ungu dengan menggunakan dua macam pelarut, yaitu pelarut etanol-asam sitrat 3\% dan pelarut aquades-asam sitrat 3\%. Pembuatan ekstrak jagung ungu dengan pelarut aquades-asam sitrat 3\% menggunakan kondisi rotary evaporator yang diatur pada suhu $50^{\circ} \mathrm{C}$ dan tekanan 75 mbar selama 4-5 jam.

\section{Jenis analisis dan pengujian}

Analisis dan pengujian yang dilakukan adalah rendemen, kadar antosianin total (Lee, 2005), kadar fenolik total (Hu dan Xu, 2011), kadar flavonoid total (Sarepoua et al., 2015), serta aktivitas antioksidan metode 2,2-diphenyl-1-picrylhydrazyl (DPPH) dan metode ferric reducing/ antioxidant power (FRAP) menurut Kwee dan Niemeyer (2011). Rendemen ekstrak dihitung dengan berat ekstrak jagung ungu yang diperoleh $(\mathrm{mg})$ dibagi dengan berat sampel jagung ungu $(\mathrm{mg})$ dikalikan $100 \%$.

\section{Analisis data}

Data disajikan dalam bentuk rataan \pm standar deviasi. Analisis data penelitian tahap pertama dan kedua dilakukan dengan analisis varian satu jalur (One Way Anova) pada taraf signifikansi 5\%. Bila ada perbedaan signifikan, maka dilanjutkan dengan uji Least Square Difference (LSD). Analisa data penelitian tahap ketiga dengan uji-T. Antar parameter pada penelitian tahap pertama dilakukan uji korelasi Pearson bivariate. Data dianalisis menggunakan paket pengujian statistik SPSS (IBM SPSS statistics, version 18.0). 


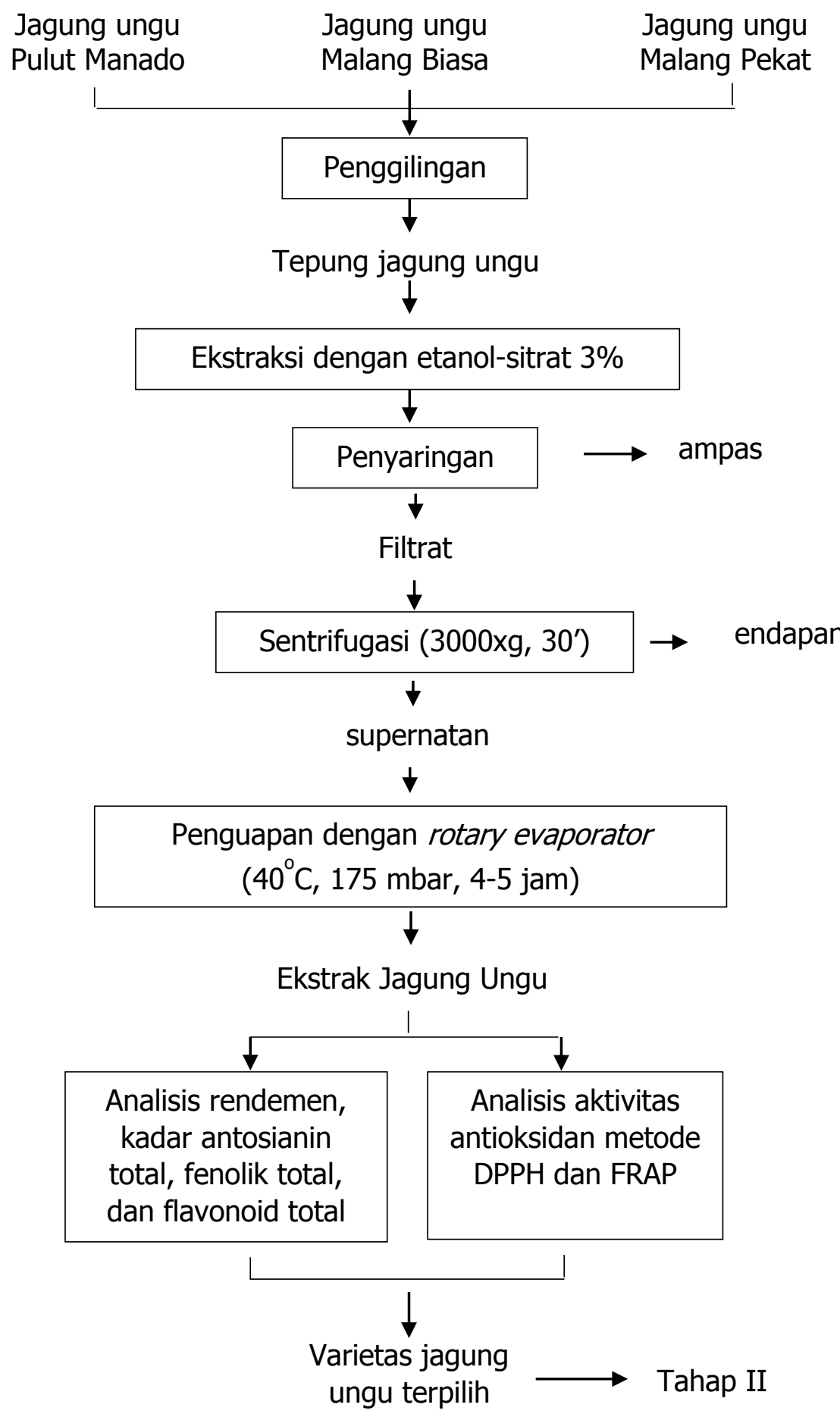

Gambar 1. Diagram alir penelitian tahap pertama: pengaruh varietas jagung ungu terhadap sifat kimiawi ekstrak jagung ungu 
Jagung ungu varietas terpilih

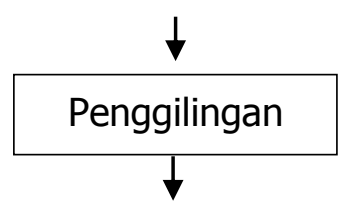

Tepung jagung ungu

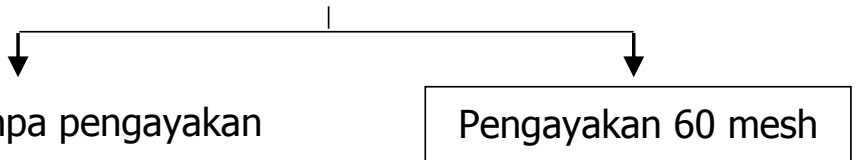

Fraksi tanpa pengayakan

Pengayakan 60 mesh
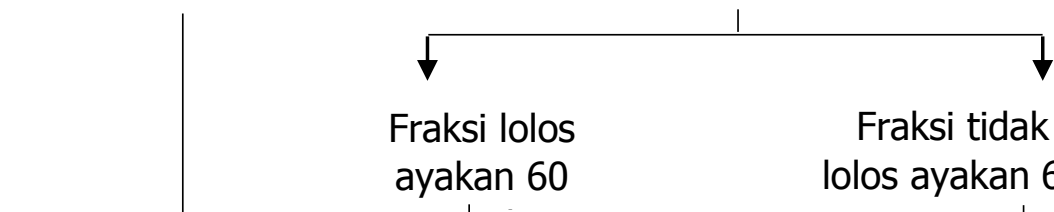

Fraksi lolos

Fraksi tidak

ayakan 60

lolos ayakan 60

Ekstraksi dengan etanol-sitrat 3\% (1:10)

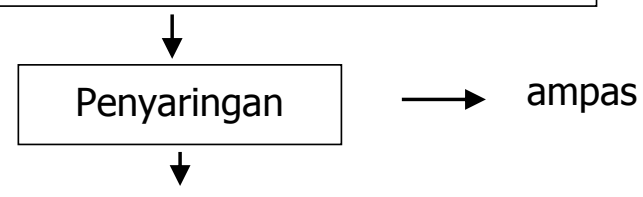

Filtrat

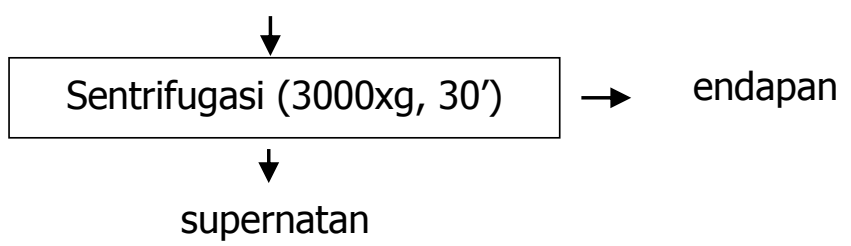

$\downarrow$

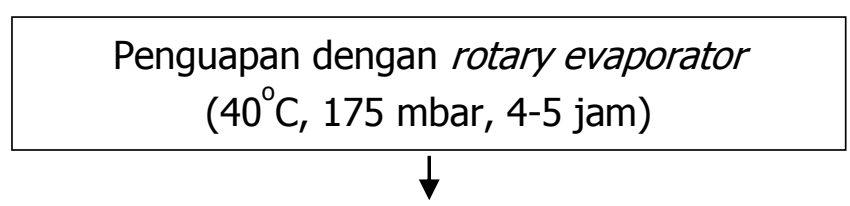

Ekstrak Jagung Ungu

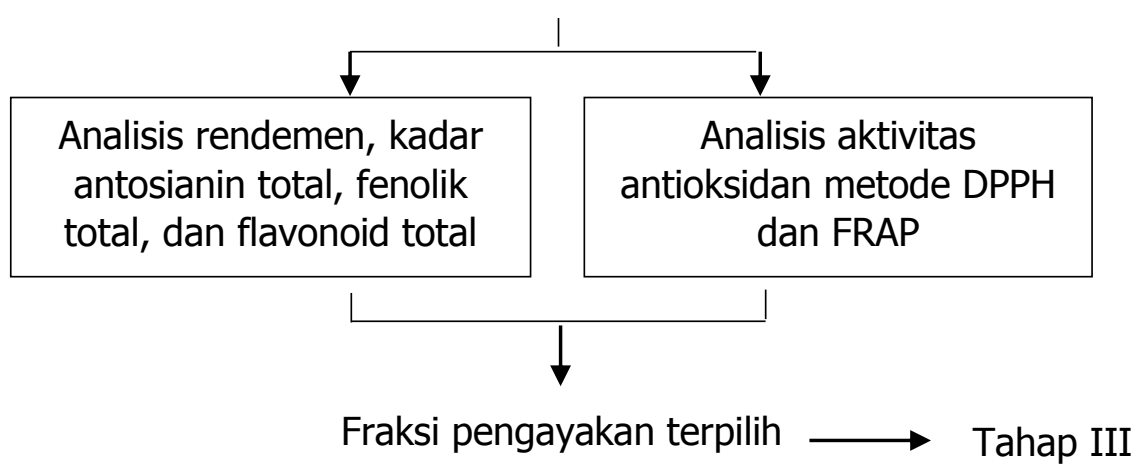

Gambar 2. Diagram alir penelitian tahap kedua: pengaruh fraksi pengayakan tepung jagung ungu terhadap sifat kimia ekstrak jagung ungu

18 Ichda Chayati, Sunarti, Yustinus Marsono, Mary Astuti

Pengaruh Varietas, Fraksi Pengayakan, dan Jenis Pelarut terhadap Kadar Antosianin, Fenolik Total, dan Aktivitas Antioksidan Ekstrak Jagung Ungu 


\section{HASIL DAN PEMBAHASAN}

\section{Pengaruh varietas terhadap kadar antosianin, fenolik total, flavonoid total, dan aktivitas antioksidan ekstrak jagung ungu}

Tabel 1 menunjukkan sifat kimiawi ekstrak jagung ungu dengan pelarut etanol-sitrat $3 \%$. Dari semua parameter kimiawi yang diuji yang meliputi kadar antosianin total, kadar fenolik total, kadar flavonoid total, aktivitas antioksidan metode DPPH dan FRAP terlihat bahwa tiga macam ekstrak jagung ungu memiliki nilai berbeda. Ekstrak jagung ungu dari Pulut Manado mempunyai nilai terendah, ekstrak jagung ungu dari Malang Biasa mempunyai nilai pertengahan, dan ekstrak jagung ungu dari Malang Pekat yang memiliki nilai paling tinggi. Hasil ini sesuai dengan peneliti lain yang menyebutkan bahwa kadar antosianin jagung ungu dipengaruhi oleh varietasnya (Harakotr et al., 2014; Ramos-Escudero et al., 2012; Zilic et al., 2012).

Tabel 1. Kadar antosianin total, fenolik total, flavonoid total, dan aktivitas antioksidan ekstrak berbagai varietas jagung ungu

\begin{tabular}{cccc}
\hline \multirow{2}{*}{ Parameter } & \multicolumn{3}{c}{ Ekstrak antosianin dari tiga varietas jagung ungu } \\
\cline { 2 - 4 } & Pulut Manado & Malang Biasa & Malang Pekat \\
\hline Rendemen $(\%)$ & 39,7 & 43,9 & 42,0 \\
Kadar antosianin total $(\mathrm{mg} \mathrm{CGE} / \mathrm{L})$ & $341 \pm 8,68^{\mathrm{a}}$ & $376 \pm 15,0^{\mathrm{a}}$ & $2.394 \pm 17,4^{\mathrm{b}}$ \\
Kadar fenolik total $(\mathrm{mg} \mathrm{GAE} / \mathrm{L})$ & $2.203 \pm 46,2^{\mathrm{a}}$ & $2.957 \pm 26,6^{\mathrm{b}}$ & $5.483 \pm 53,3^{\mathrm{c}}$ \\
Kadar flavonoid total $(\mu \mathrm{gEE} / \mathrm{L})$ & $385 \pm 12,0^{\mathrm{a}}$ & $475 \pm 12,0^{\mathrm{b}}$ & $3.285 \pm 41,5^{\mathrm{c}}$ \\
Aktivitas antioksidan metode DPPH $(\mu \mathrm{mol} \mathrm{TE} / \mathrm{L})$ & $712 \pm 13,7^{\mathrm{a}}$ & $854 \pm 10,3^{\mathrm{b}}$ & $8.454 \pm 85,6^{\mathrm{c}}$ \\
Aktivitas antioksidan metode FRAP $(\mu \mathrm{mol} \mathrm{TE} / \mathrm{L})$ & $3.039 \pm 82,5^{\mathrm{a}}$ & $3.897 \pm 82,5^{\mathrm{b}}$ & $9.611 \pm 82,5^{\mathrm{c}}$ \\
\hline a,b,c huruf yang berbeda pada baris yang sama menunjukkan berbeda nyata pada taraf signifikansi 5\%; \\
$n=3$
\end{tabular}

Pengukuran aktivitas antioksidan dalam penelitian ini menggunakan dua metode, yaitu DPPH dan FRAP. Metode DPPH mengukur aktivitas pemerangkapan radikal berbagai macam antioksidan karena bahan yang diuji bereaksi dengan radikal bebas dari DPPH•. Metode FRAP mengukur kemampuan antioksidan dalam mereduksi ferri menjadi ferro (Mojzer et al., 2016). Hasil penelitian menunjukkan aktivitas antioksidan dari ekstrak jagung ungu mepunyai nilai lebih tinggi pada mengukuran menggunakan metode FRAP daripada metode DPPH, hal ini mengindikasikan bahwa antosianin dalam jagung ungu mempunyai kemampuan mereduksi ion logam yang lebih besar daripada kemampuannya dalam memerangkap radikal bebas. Hasil pengujian FRAP yang tinggi memberikan indikasi bahwa kemungkinan antosianin mempunyai aktivitas mereduksi ferri melawan oksidan dalam saluran pencernaan. Selain itu, kemampuan mereduksi ferri menjadi ferro juga berperan penting dalam jaringan mamalia untuk menghambat peroksidasi lipid yang diinisiasi oleh transisi ion logam seperti ferri dan cupri (Muller et al., 2011).

Analisis korelasi Pearson bivariate dilakukan untuk mengetahui hubungan antara kadar antosianin total, kadar fenolik total, kadar flavonoid total, aktivitas antioksidan metode DPPH dan FRAP jagung ungu dari tiga varietas dan hasilnya disajikan pada Tabel 2 . Tabel 2 menunjukkan bahwa untuk ekstrak dari tiga varietas jagung ungu yang diuji, kadar antosianin total berkorelasi positif dengan semua parameter lain pada taraf signifikansi $99 \%$. Hasil ini menguatkan penelitian sebelumnya bahwa kadar antosianin total jagung ungu berkorelasi positif dengan kadar fenolik total, kadar flavonoid total, dan aktivitas antioksidan (Harakotr et al., 2014). 
Tabel 2. Korelasi Pearson bivariate antara kadar antosianin total, kadar fenolik total, kadar flavonoid total, aktivitas antioksidan metode DPPH dan FRAP ekstrak dari berbagai varietas jagung ungu

\begin{tabular}{|c|c|c|c|c|}
\hline & $\begin{array}{l}\text { Kadar } \\
\text { antosianin } \\
\text { total }\end{array}$ & $\begin{array}{c}\text { Kadar } \\
\text { fenolik total }\end{array}$ & $\begin{array}{l}\text { Kadar } \\
\text { flavonoid } \\
\text { total }\end{array}$ & $\begin{array}{c}\text { Aktivitas } \\
\text { antioksidan } \\
\text { metode DPPH }\end{array}$ \\
\hline Kadar fenolik total & $0,946 * *$ & & & \\
\hline Kadar flavonoid total & $0,995 * *$ & $0,965^{* *}$ & & \\
\hline Aktivitas antioksidan metode DPPH & $0,994 * *$ & $0,969 * *$ & $0,999 * *$ & \\
\hline Aktivitas antioksidan metode FRAP & $0,858^{* *}$ & $0,976 * *$ & $0,889 * *$ & $0,896 * *$ \\
\hline
\end{tabular}

Pengukuran aktivitas antioksidan metode DPPH didasarkan pada kemampuan senyawa antioksidan dalam memerangkap radikal DPPH., sementara pengukuran aktivitas antioksidan metode FRAP didasarkan pada kemampuan mereduksi kompleks ferri-TPTZ (2,4,6-tri(2piridil)-s-triazine). Aktivitas pereduksi ferri terutama dipengaruhi oleh banyaknya ikatan rangkap terkonjugasi. Hasil yang diperoleh menunjukkan bahwa varietas jagung ungu yang mempunyai kadar antosianin total yang tinggi juga mempunyai kadar fenolik total yang tinggi dan kadar flavonoid total yang tinggi juga. Varietas jagung ungu yang mempunyai kapasitas pemerangkapan radikal bebas yang kuat juga mempunyai kemampuan pereduksi yang kuat, dan sifat ini dipengaruhi oleh komponen fenolik dan flavonoid yang terdapat di dalamnya (Malaver et al., 2015).

Hasil yang ditunjukkan oleh penelitian tahap pertama adalah bahwa ekstrak jagung ungu Malang Pekat mempunyai kadar antosianin total, fenolik total, flavonoid total, dan aktivitas antioksidan tertinggi. Oleh karena itu, dalam penelitian tahap kedua digunakan jagung ungu Malang Pekat sebagai bahan baku selanjutnya.

\section{Pengaruh fraksi pengayakan terhadap kadar antosianin total, fenolik total, flavonoid total, dan aktivitas antioksidan ekstrak jagung ungu}

Secara visual, tepung jagung ungu Malang Pekat yang lolos ayakan berukuran 60 mesh mempunyai warna putih sedikit ungu, sementara yang tidak lolos ayakan berwarna ungu. Hal ini mengindikasikan bahwa kemungkinan terdapat perbedaan kadar antosianin total dari kedua fraksi tepung jagung ungu. Hasil pengujian terhadap kadar antosianin, fenolik total, flavonoid total, dan aktivitas antioksidan dapat dilihat pada Tabel 3.

Tabel 3 menunjukkan sifat kimiawi ekstrak jagung ungu Malang Pekat dan dua fraksi pengayakan, dibandingkan fraksi tanpa pengayakan. Tabel tersebut menunjukkan bahwa untuk semua parameter yang dianalisis, yaitu kadar antosianin total, kadar fenolatik total, kadar flavonoid total, dan aktivitas antioksidan metode DPPH dan FRAP, ekstrak jagung ungu dari fraksi yang tidak lolos pengayakan 60 mesh adalah paling tinggi, diikuti fraksi tanpa pengayakan, dan paling rendah adalah ekstrak dari fraksi lolos pengayakan.

Tabel 3. Kadar antosianin total, fenolik total, flavonoid total, dan aktivitas antioksidan dari ekstrak antosianin Malang Pekat berdasarkan fraksi pengayakan tepung 


\begin{tabular}{cccc}
\hline \multirow{2}{*}{ Parameter } & \multicolumn{3}{c}{ Ekstrak antosianin dari fraksi pengayakan } \\
\cline { 2 - 4 } & $\begin{array}{c}\text { Tanpa } \\
\text { pengayakan }\end{array}$ & $\begin{array}{c}\text { Lolos } \\
\text { pengayakan }\end{array}$ & $\begin{array}{c}\text { Tidak lolos } \\
\text { pengayakan }\end{array}$ \\
\hline Kadar antosianin total $(\mathrm{mg} \mathrm{CGE/} \mathrm{L)}$ & $2.394 \pm 17,4^{\mathrm{b}}$ & $1.181 \pm 23,3^{\mathrm{a}}$ & $2.553 \pm 48,6^{\mathrm{c}}$ \\
Kadar fenolik total $(\mathrm{mg} \mathrm{GAE} / \mathrm{L})$ & $5.483 \pm 53,3^{\mathrm{b}}$ & $4.452 \pm 112^{\mathrm{a}}$ & $5.615 \pm 71,9^{\mathrm{c}}$ \\
Kadar flavonoid total $(\mu \mathrm{gE} / \mathrm{L})$ & $3.285 \pm 41,5^{\mathrm{b}}$ & $1.948 \pm 52,1^{\mathrm{a}}$ & $4.541 \pm 40,4^{\mathrm{c}}$ \\
Aktivitas antioksidan metode DPPH $(\mu \mathrm{mol}$ TE/ L) & $8.454 \pm 85,6^{\mathrm{b}}$ & $7.289 \pm 94,2^{\mathrm{a}}$ & $11.212 \pm 148^{\mathrm{c}}$ \\
Aktivitas antioksidan metode FRAP $(\mu \mathrm{mol}$ TE/ L) & $9.611 \pm 82,5^{\mathrm{b}}$ & $7.497 \pm 124^{\mathrm{a}}$ & $18.030 \pm 18,0^{\mathrm{c}}$ \\
\hline
\end{tabular}

$a, b, c$ huruf yang berbeda pada baris yang sama menunjukkan berbeda nyata pada taraf signifikansi $5 \% ; n=3$

Hasil ini sejalan dengan peneliti lain yang menyebutkan bahwa antosianin terutama terdapat pada kulit biji dan menentukan warna dan intensitas warna secara keseluruhan (Beninger dan Hosfield, 2003). Jing (2006) juga menyebutkan bahwa antosianin pada kulit biji berkontribusi paling besar terhadap persentase kadar antosianin biji total. Kadar antosianin berkisar 504-1473 mg/ 100g pada kulit biji, sedangkan dalam biji berkisar 54,4-115 mg/ 100g untuk varietas Arrocillo, Conico, Peruano dan Purepecha.

Hasil penelitian yang diperoleh pada tahap kedua ini mengindikasikan bahwa fraksi tidak lolos pengayakan 60 mesh memiliki kadar antosianin total, total fenolik total, flavonoid total, dan aktivitas antioksidan lebih tinggi daripada fraksi tanpa pengayakan dan fraksi lolos pengayakan, sehingga pada penelitian tahap ketiga digunakan fraksi tidak lolos pengayakan 60 mesh sebagai bahan baku dalam pembuatan ekstrak jagung ungu. Hasil penelitian ini sejalan dengan penelitian Jung et al. (2016) yang menyebutkan bahwa kecepatan ekstraksi antosianin terbesar didapat pada tepung kentang ungu yang lolos ayakan 40 mesh tetapi tidak lolos ayakan 60 mesh. Oleh karena itu, untuk pembuatan ekstrak jagung ungu selanjutnya, tepung jagung ungu dibuat dengan jagung ungu digiling dan diayak, fraksi yang tidak lolos ayakan digiling lagi namun tidak diayak, langsung digunakan untuk pembuatan ekstrak. Fungsi penggilingan kedua adalah untuk lebih menghaluskan tepung sehingga komponen antosianin yang terekstrak lebih banyak.

Proses penggilingan adalah proses penting dalam pengecilan ukuran. Penelitian oleh Jung et al. (2016) menunjukkan bahwa kecepatan ekstraksi antosianin meningkat dengan ukuran partikel yang kecil. Hal ini disebabkan dengan proses pengecilan ukuran, maka luas permukaan per unit volume partikel akan meningkat. Ukuran partikel yang lebih kecil meningkatkan kecepatan reaksi biokimia, tetapi ada batasan ukuran partikel karena ukuran partikel yang terlalu kecil menyebabkan kadar antosianin yang terekstrak lebih rendah. Penelitian ekstraksi antosianin dari kentang ungu menggunakan ayakan 18, 30, 40, 60, dan 100 mesh menunjukkan bahwa kadar antosianin tertinggi diperoleh pada ekstraksi tepung yang lolos ayakan 40 mesh dan tidak lolos 60 mesh. Ukuran partikel yang terlalu kecil menyebabkan "fenomena paket", yaitu terlalu kecilnya jarak antar partikel sehingga pelarut sulit melakukan penetrasi ke dalam partikel.

Satu hasil penting dari penelitian tahap kedua adalah fraksi tepung tidak lolos ayakan 60 mesh mengandung antosianin lebih tinggi daripada fraksi tanpa pengayakan dan fraksi yang lolos ayakan 60 mesh. Hasil ini memberikan keuntungan besar dalam hal aplikasi atau pemanfaatan tepung jagung ungu dalam pengolahan produk, karena secara umum, tepung 
jagung yang tidak lolos ayakan adalah bagian yang tidak dimanfaatkan atau menjadi limbah. Jagung ungu bagian yang tidak lolos ayakan dimanfaatkan sebagai sumber antosianin, sementara bagian yang lolos ayakan dapat dimanfaatkan sebagai bahan baku pembuatan beras jagung, mie jagung, atau produk lain.

\section{Pengaruh jenis pelarut terhadap kadar antosianin total, fenolik total, flavonoid total, dan aktivitas antioksidan ekstrak jagung ungu}

Tabel 4 memperlihatkan kadar antosianin total, fenolik total, flavonoid total, dan aktivitas antioksidan ekstrak jagung ungu Malang Pekat dengan menggunakan pelarut etanolsitrat 3\% dan aquades-sitrat 3\%.

Tabel 4. Kadar antosianin total, fenolik total, flavonoid total, dan aktivitas antioksidan ekstrak Malang Pekat dengan pelarut etanol-sitrat 3\% dan aquades-sitrat 3\%

\begin{tabular}{|c|c|c|}
\hline \multirow[b]{2}{*}{ Parameter } & \multicolumn{2}{|c|}{ Ekstrak jagung ungu menggunakan pelarut } \\
\hline & $\begin{array}{c}\text { Etanol-asam sitrat } \\
3 \%\end{array}$ & $\begin{array}{c}\text { Aquades-asam sitrat } \\
3 \%\end{array}$ \\
\hline Rendemen (\%) & $42,5+3,89^{a}$ & $51,2+10,3^{b}$ \\
\hline Kadar antosianin total (mg CGE/ L) & $2.553+48,6^{a}$ & $734 \pm 142^{b}$ \\
\hline Kadar fenolik total (mg GAE/ L) & $5.615 \pm 71,9^{a}$ & $2.747 \pm 71,9^{b}$ \\
\hline Kadar flavonoid total ( $\mu \mathrm{g} \mathrm{RE} / \mathrm{L}$ ) & $4.541+40,4^{a}$ & $2.451+23,4^{b}$ \\
\hline Aktivitas antioksidan metode DPPH ( $\mu$ mol TE/ L) & $11.212+148^{a}$ & $6.352+148^{b}$ \\
\hline Aktivitas antioksidan metode FRAP ( $\mu \mathrm{mol}$ TE/ L) & $18.030 \pm 18,0^{\mathrm{a}}$ & $8.637 \pm 8,64^{b}$ \\
\hline
\end{tabular}

$a, b$ huruf yang berbeda pada baris yang sama menunjukkan berbeda nyata pada taraf signifikansi $5 \%$; $n=3$

Tabel 4 menunjukkan bahwa perbedaan pelarut menyebabkan perbedaan kadar dari parameter yang diuji. Hasil tersebut menunjukkan bahwa dari semua parameter yang dianalisis, pelarut etanol-sitat 3\% menunjukkan hasil yang lebih tinggi daripada pelarut aquades-sitrat. Penelitian ini mendapatkan hasil yang serupa dengan penelitian Oancea et al. (2012) yang menyebutkan bahwa penggunaan pelarut etanol menghasilkan kadar antosianin lebih tinggi daripada pelarut aquades dalam ekstraksi antosianin buah blue berry. Perbedaan hasil ini disebabkan oleh perbedaan polaritas antara etanol dan aquades sehingga komponen yang tereksktrak juga berbeda.

Antosianin adalah komponen yang bersifat polar karena mempunyai cincin aromatik yang mengandung gugus bersifat polar $\left(-\mathrm{OH},-\mathrm{C}=0\right.$, atau $\left.-\mathrm{OCH}_{3}\right)$ dan residu glukosil sehingga secara keseluruhan merupakan molekul polar (Martin et al., 2017). Proses ekstraksi antosianin yang bersifat polar membutuhkan pelarut yang juga bersifat polar, seperti air, methanol, etanol, aseton, etil-asetat, n-butanol, propilen glikol, dan kombinasinya. Etanol dikenal sebagai pelarut yang baik untuk ekstraksi polifenol dan aman untuk konsumsi manusia. Polaritas air lebih besar dan rantainya lebih pendek daripada etanol. Air dan etanol mempunyai gugus hidroksil dan dapat membentuk ikatan hidrogen dengan komponen bioaktif. Efisiensi ekstraksi terutama dipengaruhi oleh pemilihan pelarut. Polaritas komponen target adalah faktor paling penting untuk pemilihan pelarut. Selain itu, juga perlu dipertimbangkan saat pemilihan pelarut adalah afinitas molar antara pelarut dan bahan yang dilarutkan, transfer massa, toksisitas, dan perhitungan ekonomis (Lao, 2016). Pemilihan pelarut yang tepat dapat 
mengekstraksi antosianin. Hal ini disebabkan oleh kemampuan pelarut tersebut dalam mendenaturasi membran sel serta melarutkan dan menstabilkan antosianin (Martin et al., 2017).

Penelitian ini menggunakan pelarut etanol-asam dan aquades-asam untuk mengekstraksi antosianin dari jagung ungu dengan pertimbangan etanol dan aquades adalah pelarut yang aman dibandingkan pelarut lain misalnya aseton dan metanol, meskipun penelitian Jing (2006) menunjukkan bahwa penggunaan pelarut aseton dan metanol menghasilkan kadar antosianin total yang lebih tinggi dalam ekstrak dibandingkan penggunaan pelarut etanol dan aquades. Penelitian ini menggunakan pelarut etanol dan bukan metanol karena metanol bersifat toksik dan dengan pertimbangan bahwa pemanfaatan ekstrak lebih lanjut lebih aman jika menggunakan pelarut etanol (Oancea et al., 2012).

Penggunaan asam bertujuan untuk menstabilkan antosianin karena antosianin stabil pada $\mathrm{pH}$ rendah. Asam yang dipilih adalah asam sitrat karena termasuk jenis asam lemah sehingga kerusakan antosianin karena degradasi gugus non-asil dapat diminimalkan. Selain itu, asam lemah juga memberikan lingkungan yang sesuai untuk pembentukan garam klorida flavylum. Penggunaan asam kuat, seperti $\mathrm{HCl}$, dapat menghidrolisis gugus asil, co-pigmen, atau kompleks logam yang merupakan bagian dari antosianin dan berperan pada stabilitasnya (Oancea et al., 2012).

Hasil yang diperoleh dari penelitian tahap ketiga adalah bahwa ekstrak antosianin jagung ungu yang dibuat menggunakan pelarut etanol-sitrat $3 \%$ memberikan kadar antosianin yang lebih tinggi daripada pelarut aquades-sitrat $3 \%$. Penelitian tahap pertama sampai ketiga mendapatkan hasil bahwa untuk pembuatan ekstrak jagung ungu dengan kadar antosianin tertinggi adalah dengan menggunakan jagung ungu varietas Malang Pekat yang tidak lolos ayakan 60 mesh dengan menggunakan pelarut etanol-sitrat $3 \%$.

\section{KESIMPULAN}

Ekstrak antosianin dari jagung ungu Malang Pekat mempunyai kadar antosianin total, fenolik total, flavonoid total, dan aktivitas antioksidan yang lebih tinggi dibandingkan jagung ungu Pulut Manado dan Malang Biasa. Kadar antosianin total di dalam ekstrak jagung ungu berkorelasi positif dengan kadar fenolik total, flavonoid total, dan aktivitas antioksidannya. Ekstrak dari fraksi tepung jagung ungu yang tidak lolos pengayakan 60 mesh mempunyai kadar antosianin total, fenolik total, flavonoid total, dan aktivitas antioksidan yang lebih tinggi dibandingkan fraksi yang lolos pengayakan 60 mesh dan tanpa pengayakan. Ekstrak antosianin jagung ungu yang dibuat dengan pelarut etanol-asam sitrat 3\% mempunyai kadar antosianin total, fenolik total, flavonoid total, dan aktivitas antioksidan yang lebih tinggi dibandingkan yang dibuat dengan pelarut aquades-asam sitrat 3\%. Ekstrak jagung ungu varietas Malang Pekat dari fraksi yang tidak lolos ayakan 60 mesh dan menggunakan pelarut etanol-sitrat 3\% mempunyai kadar antosianin total $2.553+48,6 \mathrm{mg} \mathrm{CGE} / \mathrm{L}$, kadar fenolik total 5.615+71,9 mg GAE/ L, kadar flavonoid total 4.541+40,4 $\mu \mathrm{g}$ RE/ L, aktivitas antioksidan metode DPPH $11.212+148 \mu \mathrm{mol}$ TE/ $\mathrm{L}$, dan aktivitas antioksidan metode FRAP $18.030+18,0 \mu \mathrm{mol}$ TE/ $\mathrm{L}$.

\section{UCAPAN TERIMA KASIH}

Ucapan terima kasih disampaikan kepada Kementerian Riset, Teknologi dan Pendidikan Tinggi yang telah memberikan Beasiswa Pendidikan Pascasarjana Dalam Negeri (BPPDN), 
kepada Ir. M. Yasin H. Gaffar dari Balai Penelitian Tanaman Serealia di Maros, Sulawesi Selatan yang telah memberikan benih jagung ungu varietas Pulut Manado, juga kepada Ir. Arifin Noor Sugiharto, M.Sc., Ph.D., staf pengajar dari Fakultas Pertanian Universitas Brawijaya, Malang yang telah memberikan benih jagung ungu dengan varietas Malang Biasa dan Malang Pekat.

\section{DAFTAR PUSTAKA}

Balai Penelitian Tanaman Serealia, 2018. Balitbangtan Resmi Melepas Jagung Ungu Pertama di Indonesia. http://balitsereal.litbang.pertanian.go.id/balitbangtan-resmi-melepasjagung-ungu-pertama-di-indonesia/. Diakses tanggal 23 Desember 2019

Beninger, C. W., dan Hosfield, G. L. 2003. Antioxidant activity of extracts, condensed tannin fractions, and pure flavonoids from Phaseolus vulgaris L. seed coat color genotypes. Journal of Agricultural and Food Chemistry, 51(27), 7879-7883. http://doi.org/10.1021/jf0304324

Bouayed, J., dan Bohn, T. 2010. Exogenous Antioxidants-Double-Edged Swords in Cellular Redox State: Health Beneficial Effects at Physiologic Doses versus Deleterious Effects at High Doses. Oxidative Medicine and Cellular Longevity, 3(4), 228-237. https://doi.org/10.4161/oxim.3.4.12858

Fernandez- Aulis, F., Hernandez- Vazquez, L., Aguilar- Osorio, G., Arrieta- Baez, D., \& NavarroOcana, A. (2019). Extraction and Identification of Anthocyanins in Corn Cob and Corn Husk from Cacahuacintle Maize. Journal of Food Science, 84(5), 954-962. https://doi.org/10.1111/1750-3841.14589

Firmansyah, T. 2018. Mentan Tertarik Pengembangan Jagung Ungu. https://www.republika.co.id/berita/ekonomi/pertanian/18/05/30/p9iovt377-mentantertarik-pengembangan-jagung-ungu. Diakses tanggal 23 Desember 2019

Halliwell, B. 2007. Biochemistry of Oxidative Stress. Biochemical Society Transactions, 35(5), 1147-1150. http://doi.org/10.1042/BST0351147

Harakotr, B., Suriharn, B., Tangwongchai, R., Scott, M. P., dan Lertrat, K. 2014. Anthocyanins and antioxidant activity in coloured waxy corn at different maturation stages. Journal of Functional Foods, 9, 109-118. https://doi.org/10.1016/j.jff.2014.04.012

Hu, Q.P., dan Xu, J.G. 2011. Profiles of carotenoids, anthocyanins, phenolics, and antioxidant activity of selected color waxy corn grains during maturation. Journal of Agricultural and Food Chemistry, 59(5), 2026-2033. https://doi.org/10.1021/jf104149q

Jing, P. 2006. Purple corn anthocyanins: chemical structure, chemoprotective activity and structure / function relationships. Disertasi. The Ohio State University. Columbus. Ohio

Jung, H., Pan, C., dan Yoon, W. B. 2016. Mathematical models of pretreatment processes to utilize purple-fleshed potato (Solanum tuberosum L.) peels for anthocyanin extraction. Food Science and Biotechnology, 25(5), 1361-1367. http://doi.org/10.1007/s10068$\underline{016-0213-5}$

Khoo, H.E. 2017. Anthocyanidins and anthocyanins : colored pigments as food, pharmaceutical ingredients, and the potential health benefits. Food Nutr Res, 61(1): 1-21. https://doi.org/10.1080/16546628.2017.1361779

Kurutas, E. B. 2016. The importance of antioxidants which play the role in cellular response against oxidative/nitrosative stress: current state. Nutrition Journal, 15: 71. http://doi.org/10.1186/s12937-016-0186-5

Kwee, E. M. dan Niemeyer, E. D. 2011. Variations in phenolic composition and antioxidant properties among 15 basil (Ocimum basilicum L.) cultivars. Food Chemistry, 128(4), 1044-1050. https://doi.org/10.1016/j.foodchem.2011.04.011

Lao, F. 2016. Purple Corn (Zea mays L.) Cob Anthocyanins: Extraction, Quantification, Spray Drying and Complexation with Proteins. Disertasi. The Ohio State University. Ohio 
Lee, J. 2005. Determination of total monomeric anthocyanin pigment content of fruit juices, beverages, natural colorants, and wines by the $\mathrm{pH}$ differential method: collaborative study. Journal of AOAC International. 88(5): 1269-1278.

Li, C.Y., Kim, H.W., Li, H., Lee, D.C., dan Rhee, H.I. 2014. Antioxidative effect of purple corn extracts during storage of mayonnaise. Food Chemistry, 152, 592-596. https://doi.org/10.1016/j.foodchem.2013.11.152

Malaver, C.L.V, Dulcey, A.J.C., dan Martínez, J.H.I. 2015. Comparison of DPPH Free Radical Scavenging, Ferric Reducing Antioxidant Power (FRAP), and Total Phenolic Content of Two Meriania Species (Melastomataceae). Revista de Ciencias, 19(2), 117-124.

Martín, J., Navas, M.J., Jiménez-Moreno, A.M. dan Asuero, A.G., 2017. Anthocyanin pigments: Importance, sample preparation and extraction. Phenolic compounds-Natural sources, importance and applications. InTech, pp.117-152.

Mojzer, E.B., Hrnčič, M.K., Škerget, M., Knez, Ž., dan Bren, U. 2016. Polyphenols: extraction methods, antioxidative action, bioavailability and anticarcinogenic effects. Molecules, 21(7), 901. http://doi.org/10.3390/molecules21070901

Müller, L., Fröhlich, K., dan Böhm, V. 2011. Comparative antioxidant activities of carotenoids measured by ferric reducing antioxidant power (FRAP), ABTS bleaching assay (aTEAC), DPPH assay and peroxyl radical scavenging assay. Food Chemistry, 129(1), 139-148. http://doi.org/10.1016/j.foodchem.2011.04.045

Napan, L.E., Vietti-Guzmán, F.F., Alvarez-Yanamango, E.G., dan Huayta, F.V. (2018). Evaluation of some functional properties of purple corn (Zea mays L.) dye, during its processing at pilot scale. 16th LACCEI International Multi-Conference for Engineering, Education, and Technology: "Innovation in Education and Inclusion", 19-21 July 2018, Lima, Peru. http://dx.doi.org/10.18687/LACCEI2018.1.1.290

Oancea, S., Stoia, M., dan Coman, D. (2012). Effects of extraction conditions on bioactive anthocyanin content of Vaccinium corymbosum in the perspective of food applications. Procedia Engineering, 42, 489-495. https://doi.org/10.1016/j.proeng.2012.07.440

Rahal, A., Kumar, A., Singh, V., Yadav, B., Tiwari, R., Chakraborty, S., dan Dhama, K. 2014. Oxidative stress, prooxidants, and antioxidants: the interplay. BioMed research international, 2014. http://dx.doi.org/10.1155/2014/761264

Ramos-Escudero, F., Muñoz, A. M., Alvarado-Ortíz, C., Alvarado, Á., dan Yáñez, J.A. 2012. Purple corn (Zea mays L.) phenolic compounds profile and its assessment as an agent against oxidative stress in isolated mouse organs. Journal of Medicinal Food, 15(2), 206215. https://doi.org/10.1089/jmf.2010.0342

Sarepoua, E., Tangwongchai, R., Suriharn, B., dan Lertrat, K. 2015. Influence of variety and harvest maturity on phytochemical content in corn silk. Food Chemistry, 169, 424-429. https://doi.org/10.1016/j.foodchem.2014.07.136

Siomek, A. 2012. NF-kB signaling pathway and free radical impact. Acta Biochimica Polonica, 59(3). http://doi.org/10.18388/abp.2012 2116

Susanti, A. 2015. Pengaruh Penambahan Rosella (Hibiscus sabdariffa L.) terhadap Sifat Fiskokimia Permen Jelly Rumput Laut Eucheuma cottonii. Jurnal Riset Teknologi Industri, 9(1): 30-40. http://dx.doi.org/10.26578/jrti.v9i1.1699

Susanti, A. dan Sampepana, E. 2017. Pengaruh Masa Simpan Buah terhadap Kualitas Sari Buah Naga Merah (Hylocereus polyrhizus). Jurnal Riset Teknologi Industri, 11(2): 76-82. http://dx.doi.org/10.26578/jrti.v11i2.3011

Wu, T., Qi, X., Liu, Y., Guo, J., Zhu, R., Chen, W., ... Yu, T. 2013. Dietary supplementation with purified mulberry (Morus australis Poir) anthocyanins suppresses body weight gain in high-fat diet fed C57BL/6 mice. Food Chemistry, 141(1), 482-487. https://doi.org/10.1016/j.foodchem.2013.03.046

Zhao, X., Zhang, C., Guigas, C., Ma, Y., Corrales, M., Tauscher, B., dan Hu, X. 2008. 
Composition, antimicrobial activity, and antiproliferative capacity of anthocyanin extracts of purple corn (Zea mays L.) from China. European Food Research and Technology, 228(5), 759-765. https://doi.org/10.1007/s00217-008-0987-7

Žilić, S., Serpen, A., Akıllıoğlu, G., Gökmen, V., dan Vančetović, J. 2012. Phenolic Compounds, Carotenoids, Anthocyanins, and Antioxidant Capacity of Colored Maize (Zea mays L.) Kernels. Japi, 60, 1224-1231. http://doi.org/10.1021/if204367z 